\title{
Effect of Hot Forging on High Temperature Tribilogical Properties of Aluminium Composite Reinforced with Agro and Industrial Waste
}

\author{
Mohanta Gopal Krushna, Panda Sasank Shekhar, Senapati Ajit Kumar
}

\begin{abstract}
Objective of the present work focus to study the effect of hot forging on high temperature tribilogical properties of aluminium composite reinforced with agro and industrial waste, i.e. fly ash and Rice husk ash. The developed MMCs are hot forged at a temp of $450^{\circ} \mathrm{C}$ with a reduction of $80 \%$ in different step. The as cast and forged alloy and its composite are subjected to microstuctural analysis and wear test. Microstuctural analysis shows uniform distribution of the particulate in the matrix alloy. After forging reinforcement RHA and $F A$ are united towards the material flow direction throughout hot forging. During hot forging, the effect of plastic deformation and high temperature lead to recrystalization of Al6061/RHA and Al6061/FA MMCs with grain refinement. Refinement of grain enhanced the mechanical strength. The worn out surfaces are seen by SEM to know the mechanism of wear. Forged composite possesses lower wear rate under all the condition compared with as cast alloy and composite. Hot forged Al6061 alloy reinforced with fly ash composite gives least wear rate at $150^{\circ} \mathrm{C}$ in comparison with its room temperature.
\end{abstract}

Key words: Al MMCs, stir casting, Fly ash, Rice husk ash, Hot Forging, wear properties

\section{INTRODUCTION}

Metal matrix composites (MMCs) particularly aluminum based composites gaining attraction towards automobile and aerospace industries because of its excellent properties, like high specific strength, low density and good abrasion resistance to wear and tear [1]. Owing to lower thermal coefficient of expansion and tolerable mach inability these materials are gaining popularity over other conventional materials [2]. Recently, researchers are dispensing with costly reinforcement materials such as $\mathrm{SiC}, \mathrm{Al}_{2} \mathrm{O}_{3}$. Normally stir casting route is adopted to manufacture component with aluminium Matrix Composite (AMC) where there is considerable drainage of costly materials i.e. $\mathrm{SiC}, \mathrm{Al}_{2} \mathrm{O}_{3}$. In order to lower the cost of production, addition of cheaper reinforcement such as fly ash, rice husk, coconut shell ash have been chosen[3]. But these materials are weaker during formability because metal matrix composites relate with particle rupture and decohesion of reinforcement. MMC produced by traditional fabrication method gives less ductility due to high brittle reinforcement, porosity and agglomeration [4].

Revised Manuscript Received on October 30, 2019.

* Correspondence Author

Mohanta Gopal Krushna1*, 1Assistant Professor, GIET, Gunupur, India,

Panda Sasank Shekhar2, 2Assistant Professor, GIET, Gunupur, India,

Senapati Ajit Kumar, 3Associate Professor, GIET, Gunupur, India,

(C) The Authors. Published by Blue Eyes Intelligence Engineering and Sciences Publication (BEIESP). This is an open access article under the CC BY-NC-ND license (http://creativecommons.org/licenses/by-nc-nd/4.0/)
As we know that hot working process like forging, rolling and extrusion of discontinuously reinforced MMCs can improve the interstitial bonding between matrix and reinforcement, particle distribution, breaking of particle agglomeration and reduce the defects of composites [5]. However most of the researcher has given attention towards the development and characterization of composite by primary processing technique, little work has been done on the effect of thermo mechanical process on the properties of composite particularly on hot forging. Amongst the secondary processes available hot forging is the best suitable methods which provide better strength, hardness because during this process plastic deformation will be takes place rapidly. Forging method offers distinct and able to reproduce the engineering components performance [6]. Venkatasiva et.al was studied the hot deformation behavior on the wear properties of $\mathrm{Al}$ composite reinforced with $\mathrm{Al}_{2} \mathrm{O}_{3}$. They have reported that hot forged composite gives an enhanced wear resistance compare to the base alloy [7]. Seo et.al investigates the effect of hot extrusion on mechanical properties of $\mathrm{Al} / \mathrm{SiCp}$ composites. They have concluded that after forging the particle are distributed uniformly with some increment [8]. Keshavamurty et al. was discussed the wear properties of $\mathrm{Al} 2024 / \mathrm{TiB}_{2}$ as cast and hot forged in situ composite. They have found that hot forged matrix alloy and its composite gives better refinement of grains. The cast and forged composite exhibit superior micro hardness, lower wear rate and COF than the unreinforced alloy [9]. Tan et al. investigate the behavior of powder processed and extruded Al-Li alloy based composite reinforced with $\mathrm{SiC}$ and found that above 20wt\% reinforcement there is a considerable decrease in yield strength and ductility [10].

In the present investigation, Al6061 alloy based metal matrix composite containing up to $12 \%$ fly ash [MMC (FA)] and $12 \%$ rice husk ash [MMC (RHA)] particulates were successfully synthesized using vortex method. Effect of hot forging on wear properties of waste material reinforced MMCs were investigated. The material developed indigenously at the laboratory is expected to be used in automobile industries for making some component such as break shoes. These materials while in use are subjected to rubbing action where temperature rises to $150^{\circ} \mathrm{c}$. In order to see integrity of the material it is thought worth to have comparative study on abrasion behavior at $150^{\circ} \mathrm{C}$.

\section{EXPERIMENTAL WORK}

In present work Al6061alloy is used as matrix, which exhibit good casting properties and strength. The chemical composition is given in (Table-1). 


\section{Effect of Hot Forging on High Temperature Tribilogical Properties of Aluminium Composite Reinforced with Agro and Industrial Waste}

Two different reinforcement is used in this study are Rice husk ash and Fly ash. The chemical composition of RHA and FA is given in the Table- $2 \& 3$.

Table-1: Composition of Al-6061 alloy

\begin{tabular}{|c|c|c|c|c|c|c|c|c|c|}
\hline $\begin{array}{l}\text { Chemical } \\
\text { Compositi } \\
\text { on }\end{array}$ & $\mathrm{Al}$ & $\mathrm{Cr}$ & $\mathrm{Cu}$ & $\mathrm{Fe}$ & $\begin{array}{l}\text { M } \\
\mathrm{g}\end{array}$ & Mn & Si & $\mathrm{Ti}$ & $\mathrm{Zn}$ \\
\hline $\mathrm{Wt} \%$ & $\begin{array}{l}95.8 \\
- \\
98.6\end{array}$ & $\begin{array}{l}0.04 \\
- \\
0.35\end{array}$ & $\begin{array}{l}0.15 \\
-0.4\end{array}$ & $\begin{array}{l}\mathrm{Ma} \\
\mathrm{X} \\
0.7\end{array}$ & $\begin{array}{l}0.8 \\
- \\
1.2\end{array}$ & $\begin{array}{l}\text { Ma } \\
\mathrm{X} \\
0.1 \\
5\end{array}$ & $\begin{array}{l}04 \\
- \\
0 . \\
8\end{array}$ & $\begin{array}{l}\text { Ma } \\
\mathrm{x} \\
0.1 \\
5\end{array}$ & $\begin{array}{l}\text { Ma } \\
\text { X } \\
0.2 \\
5\end{array}$ \\
\hline
\end{tabular}

Table-2 Chemical Composition of Fly Ash (wt \%)

\begin{tabular}{|l|c|c|c|c|c|c|c|}
\hline $\begin{array}{l}\text { Chemical } \\
\text { Composition }\end{array}$ & $\mathrm{Na}_{2} \mathrm{O}$ & $\mathrm{CaO}$ & $\mathrm{MgO}$ & $\mathrm{SiO}_{2}$ & $\mathrm{AL}_{2} \mathrm{O}_{3}$ & $\mathrm{~K}_{2} \mathrm{O}$ & $\mathrm{Fe}_{2} \mathrm{O}_{3}$ \\
\hline Wt \% & 0.10 & 1.24 & 0.58 & 56.43 & 13.54 & 0.59 & 4.97 \\
\hline
\end{tabular}

Table-3 Chemical Composition of Rice Husk Ash (wt \%)

\begin{tabular}{|l|l|l|l|l|l|l|l|l|}
\hline $\begin{array}{l}\text { Che } \\
\text { m. } \\
\text { Com } \\
\text { p. }\end{array}$ & $\begin{array}{l}\mathrm{SiO} \\
2\end{array}$ & $\begin{array}{l}\mathrm{Al}_{2} \mathrm{O} \\
3\end{array}$ & $\begin{array}{l}\mathrm{Fe}_{2} \mathrm{O} \\
3\end{array}$ & $\begin{array}{l}\mathrm{Ca} \\
\mathrm{O}\end{array}$ & $\mathrm{MgO}$ & $\mathrm{SO}_{3}$ & $\begin{array}{l}\mathrm{K}_{2} \\
\mathrm{O}\end{array}$ & $\mathrm{Na}_{2} \mathrm{O}$ \\
\hline $\mathrm{Wt} \%$ & $\begin{array}{l}97 . \\
0\end{array}$ & 1.13 & 0.31 & $\begin{array}{l}0.0 \\
7\end{array}$ & $\begin{array}{l}0.82 \\
5\end{array}$ & $\begin{array}{l}0.1 \\
4\end{array}$ & $\begin{array}{l}0.1 \\
8\end{array}$ & 0.092 \\
\hline
\end{tabular}

The metal ingots are properly cleaned before melting to eliminate surface impurities. An electrical resistance furnace with bottom pouring attachment is used for melting. The melting temperature was kept at $700^{\circ} \mathrm{C}$ then $1 \mathrm{wt} \%$ of $\mathrm{Mg}$ added to improve the wettability of reinforcement particulate in the liquid. Mechanical stirring is done for mixing the $\mathrm{Mg}$ in the melt $\mathrm{Al}$ alloy. Before pouring into the melt Rice husk ash and Fly ash are preheated to $650^{\circ} \mathrm{C}$. A $\mathrm{BN}$ coated stainless steel rotor is rotated at a speed of 600 $650 \mathrm{rpm}$ for 10 mins to create a vortex in the melting metal. Then the molten composite transferred into from crucible to a rectangular steel mould. The hot forged cast matrix alloy and its composite are cut with respect to the required dimension. The samples are heated in a furnace to a temperature of $450^{\circ} \mathrm{C}$ for $3 \mathrm{hrs}$. Continuous soaking of the sample, followed by hot forging was done with Press forging machine. The deformation was carried out slowly at different stage of forging. The initial thicknesses of strips are $20 \mathrm{~mm}$ and the working is done in steps i.e. $10 \%$ in each step. First the thickness is reduced to $8 \mathrm{~mm}$. In between each step, the strips are soaked for half an hour before the forging is resumed. Fig.1 shows the sample dimension of forged composite and cast alloy. Hot forged alloy and its composite were subjected to optical microstructure studies, hardness test and wear. For microstuctural study Optical microscope (XJL 17) and Scanning Electron Microscope (SEMJEOL/EO, JSM-6510) was used. Density was measured by Archimedean principle. Wear test was conducted by using Pin-on-disc set up at room temperature and at $150^{\circ} \mathrm{C}$. The sample size has been prepared as per ASTM; $8 \mathrm{~mm}$ diameter and $30 \mathrm{~mm}$ in length. The weight loss was calculated at constant load, RPM and time. An electric sensor is connected to the PC to get the readings for tangential forces and the Coefficient of Friction (COF).

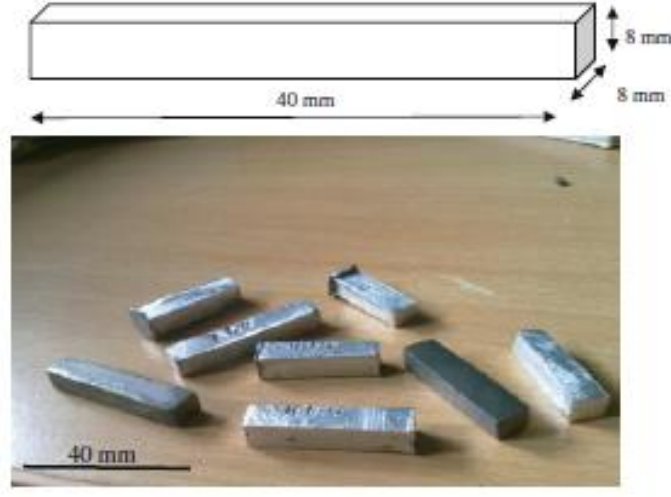

Fig. 1. Sample Dimension of Forged and as cast
composite

\section{RESULT AND DISCUSSION}

\section{A. Morphology of Rice husk ash and Fly ash}

Size and shape of the rice husk ash and Fly ash particles in the powder was observed under SEM and given in fig. 2 . The size of the RHA particles very between 5 to 10 microns and the shapes of particles are irregular and sharp edges. The size of Fly ash is in the ranges of 15 to $25 \mathrm{microns}$ and the shapes of the particles are irregular.
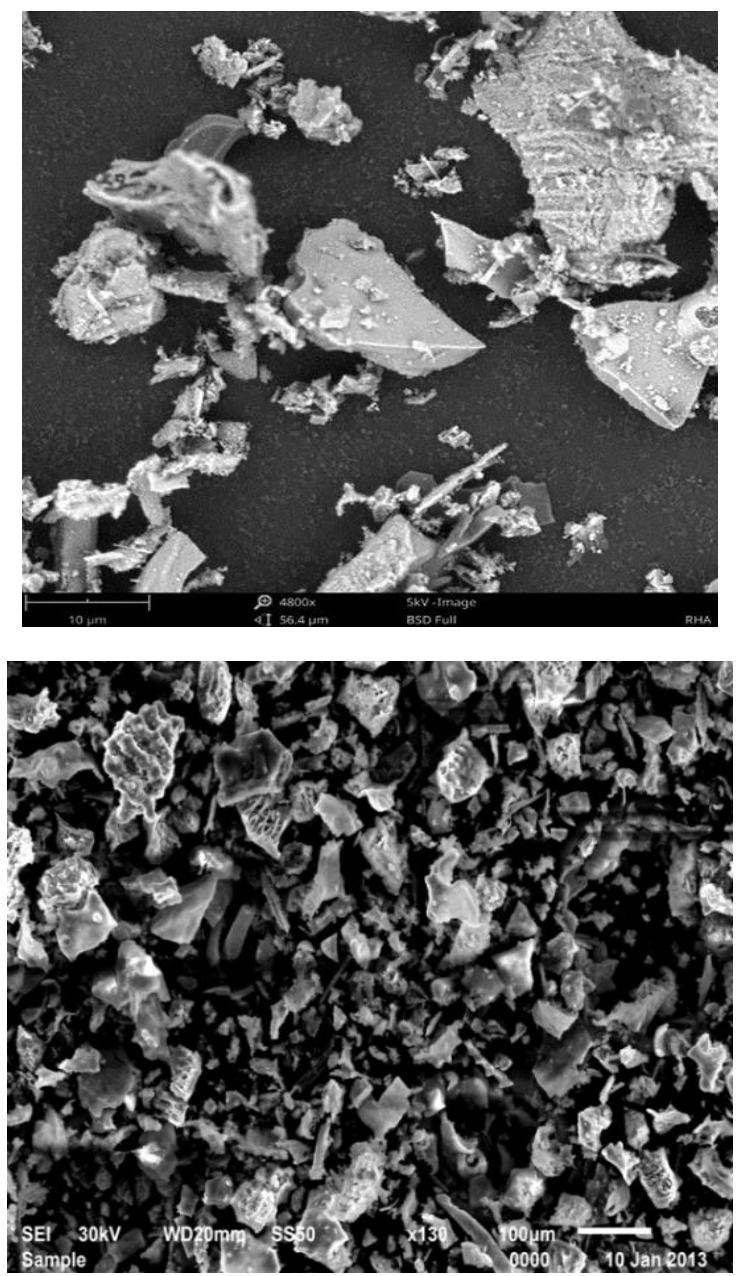

Fig. 2 : SEM micrographs of RHA and FA particles

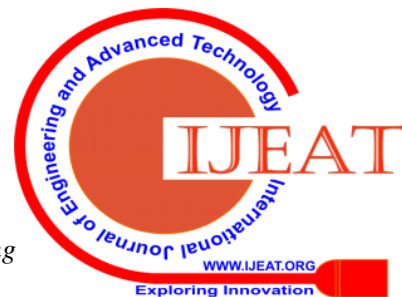




\section{B. Characterization of cast and forged Composites}

The Scanning Electron and Optical micrographs of both matrix alloy and composite in, as cast and forged condition is shown in the Fig 3. The microstructure clearly indicates that the reinforcement are distributed homogeneously in the matrix alloy.

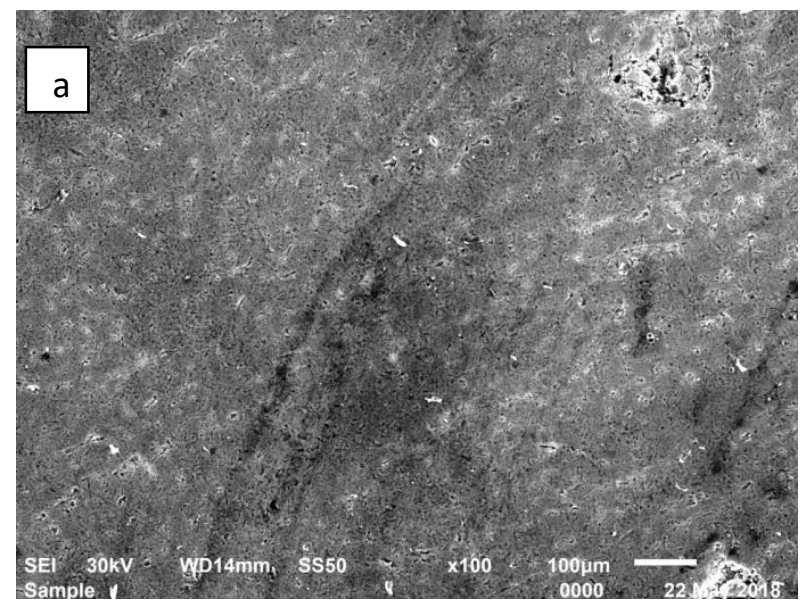

\section{Cast Al6061}

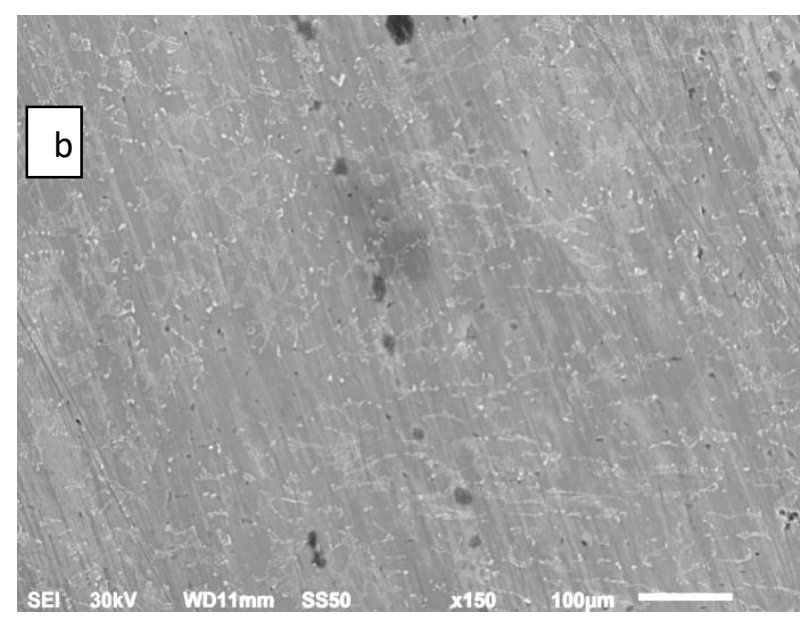

Cast Al6061/RHA

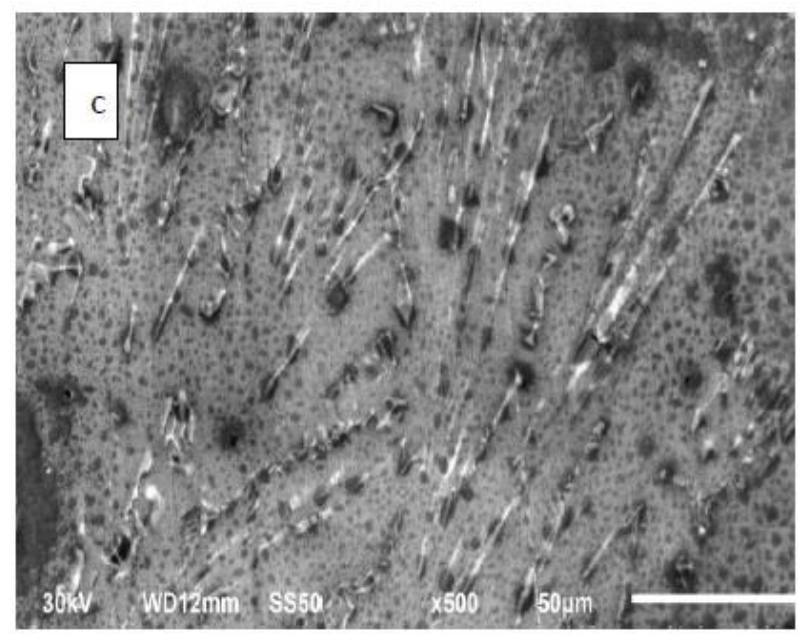

Cast Al6061/FA

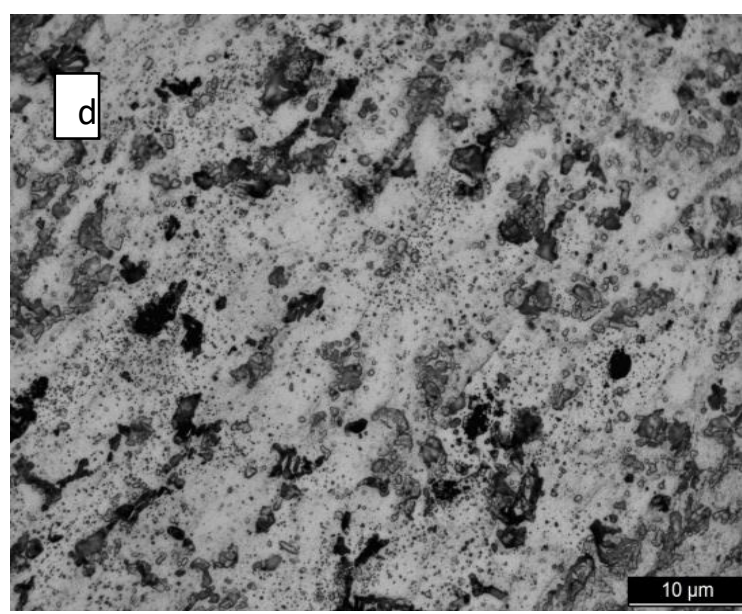

\section{Forged Al6061}

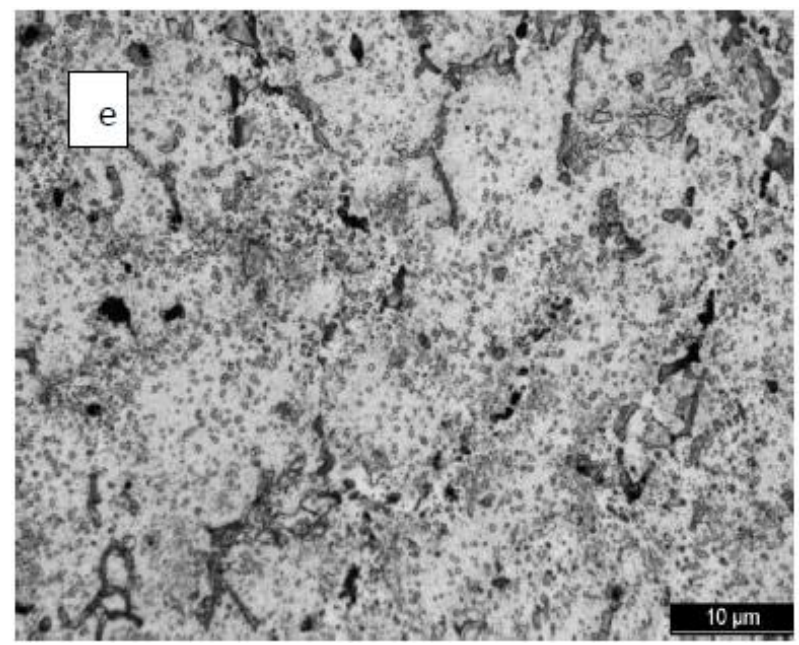

Forged Al6061/RHA

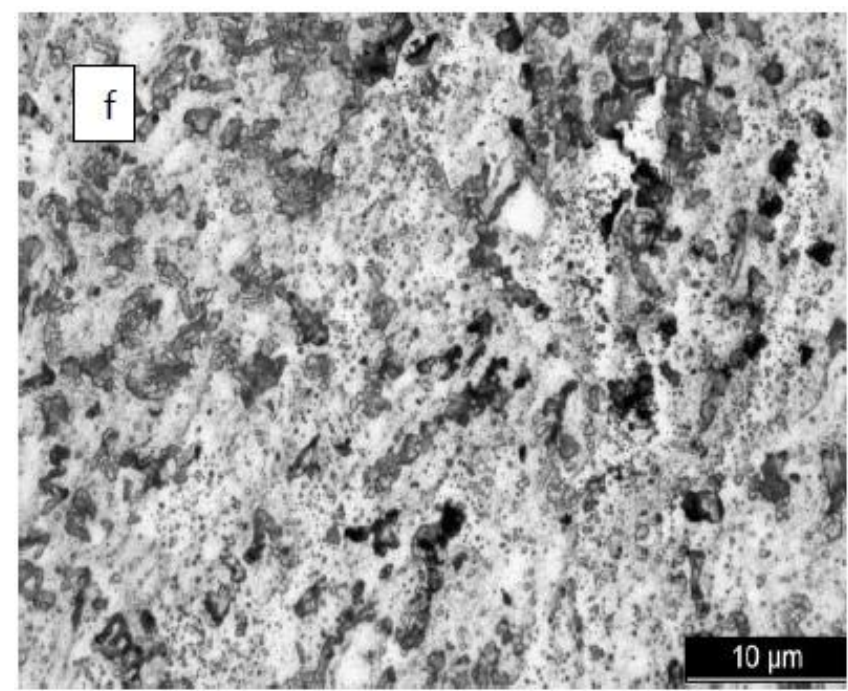

\section{Forged Al6061/FA}

Fig 3. (a-f) SEM and Optical Micrographs of cast and forged Al6061 and its composites

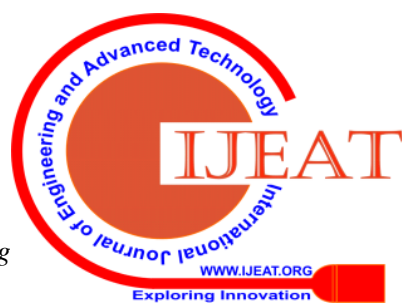




\section{Effect of Hot Forging on High Temperature Tribilogical Properties of Aluminium Composite Reinforced with Agro and Industrial Waste}

Fig 3. (a) Shows the SEM of as cast Al6061 alloy revealed the presence of dendrite structure caused by solidification. The high cooling rate during solidification forms such dendrite structure. Due to the presence of $\mathrm{Mg}$ and $\mathrm{Si}$ in a little bit higher in amount in Al-6061 alloy the inter-metallic phase, $\mathrm{Mg}_{2} \mathrm{Si}$ formed around the dendrites during casting. Fig (b) shows the image of Al6061/RHA AMC, revealed that RHA particles are distributed uniformly in Al6061 matrix alloy. It also revealed the integrity between Al-6061 and RHA. Fig(c) shows the FA particulates distributed uniformly throughout the base metal matrix. No casting defects were shown, which demonstrates the quality of casting. Uniform distribution of FA particles is essential to obtain higher mechanical properties of MMCs.

Fig 3. (d-f) shows the optical micrographs of Al6061 alloy and it's composite in hot forged condition. Form the observation it is cleared that forging lead to reduce the porosity of the cast composites because during hot forging the agglomeration of particulates breaks and bonding between matrix and reinforcement. Reinforcements, i.e. RHA and FA are dispersed in the metal matrix. After deformation due to the transfer of load from matrix to the reinforcement the mechanical bonding between matrix and reinforcement improved in the composite. It is also observed that even after hot forging the particulates are not pullout from the matrix.

\section{Density Measurement}

Density is the physical property of composite that reflects the characteristics. Table-4 shows the density of three materials as cast Al6061 alloy, RHA composite and Fly ash composite and Fig.4 show the variation of density of the base metal and other two reinforced composite. It was observed that after forging density slightly increased in three materials. This is because of the reduction of porosity in the prepared castings.

Table-4: Density of Alloy and MMCs.

\begin{tabular}{|c|c|c|c|}
\hline Material & $\begin{array}{l}\text { Cast } \\
\text { (Before } \\
\text { Forging) } \\
\text { (In } \\
\text { g/cm3) }\end{array}$ & $\begin{array}{l}\text { After } \\
\text { Forging } \\
\text { (In } \\
\text { g/cm3) }\end{array}$ & $\begin{array}{l}\text { Difference } \\
\text { (in \%age) }\end{array}$ \\
\hline $\begin{array}{l}\text { Al6061 } \\
\text { alloy }\end{array}$ & 2.611 & 2.713 & 3.9 \\
\hline $\begin{array}{l}\text { MMC } \\
\text { (RHA) }\end{array}$ & 2.571 & 2.612 & 1.6 \\
\hline MMC (FA) & 2.376 & 2.478 & 4.3 \\
\hline
\end{tabular}

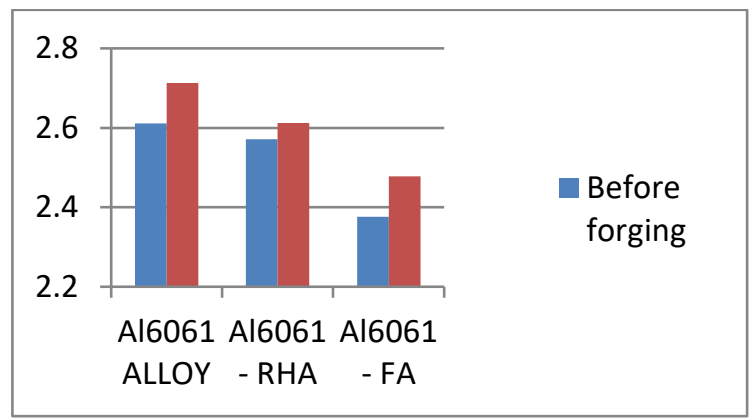

Fig.4: Variation of density before and after forging

\section{WEAR PROPERTIES}

Due to the emerge application of AMCs in automobile industries, the specimens are aligned exactly according to the wear testing method on Pin-on-disc set up. The specimens are then tested as per standard procedure. Table5, 6, $7 \& 8$ shows the result of wear behavior of the cast and forged Al6061 alloy, AMC with RHA and AMC with fly ash at $150^{\circ} \mathrm{C}$ and room temperature with constant load and rpm. From the experiment, it was shown that there is a decrement of wear rate in the hot forged composite as compare to as cast composite. Further, among all the composites study it was observed that in both the cases, the FA reinforced composite having less wear rate as compared to the base alloy and RHA reinforced composite. This is due the high bonding between the matrix and FA particulates in the composite. The composites with coarse particles have large interfacial bonding with the aluminium matrix, which avoids particle to pull out of the surface. Due to this the hardness of the composite increases and the wear rate also reduces.

Table. 5: Wear Test Result Of As Cast Sample (at Room Temp) Constant Load, Rpm, Time and Temp

\begin{tabular}{|c|c|c|c|c|c|}
\hline Material & $\begin{array}{l}\text { Initial } \\
\text { Weight } \\
\text { (in } \\
\text { gm) }\end{array}$ & $\begin{array}{l}\text { Final } \\
\text { Weight } \\
\text { (in } \\
\text { gm) }\end{array}$ & $\begin{array}{l}\text { Loss } \\
\text { Of } \\
\text { Weight } \\
\text { (in gm) }\end{array}$ & $\begin{array}{l}\text { Wear } \\
\text { Rate= } \\
\text { Vol. } \\
\text { Loss/SD } \\
\left(\mathrm{mm}^{3} / \mathrm{m}\right)\end{array}$ & $\begin{array}{l}\text { Specific } \\
\text { Wear Rate } \\
\left(\mathrm{mm}^{3} / \mathrm{Nm}\right)\end{array}$ \\
\hline $\begin{array}{l}\text { Al6061 } \\
\text { Alloy }\end{array}$ & 3.710 & 3.696 & 0.024 & 0.00613 & $0.20 \times 10^{-3}$ \\
\hline $\begin{array}{l}\text { MMC } \\
\text { (RHA) }\end{array}$ & 3.832 & 3.813 & 0.019 & 0.00460 & $0.15 \times 10^{-3}$ \\
\hline $\begin{array}{l}\text { MMC } \\
\text { (FA) }\end{array}$ & 3.881 & 3.869 & 0.012 & 0.00290 & $0.09 \times 10^{-3}$ \\
\hline
\end{tabular}

Table. 6: Wear Test Result Of As Cast Sample (At $150^{\circ} \mathrm{C}$ Temp) Constant Load, RPM, Time and Temp

\begin{tabular}{llllll}
\hline Material & $\begin{array}{l}\text { Initial } \\
\text { Weight } \\
\text { (in gm) }\end{array}$ & $\begin{array}{l}\text { Final } \\
\text { Weight } \\
\text { (in gm) }\end{array}$ & $\begin{array}{l}\text { Loss } \\
\text { Of } \\
\text { Weight } \\
\text { (in gm) }\end{array}$ & $\begin{array}{l}\text { Wear Rate= } \\
\text { Vol. } \\
\text { Loss/SD } \\
\left(\mathrm{mm}^{3} / \mathrm{m}\right)\end{array}$ & $\begin{array}{l}\text { Specific } \\
\text { Wear Rate } \\
\left(\mathrm{mm}^{3} / \mathrm{Nm}\right)\end{array}$ \\
\hline $\begin{array}{l}\text { Al6061 } \\
\text { Alloy }\end{array}$ & 3.597 & 3.580 & 0.017 & 0.00436 & $0.14 \times 10^{-3}$ \\
\hline $\begin{array}{l}\text { MMC } \\
\text { (RHA) }\end{array}$ & 3.700 & 3.692 & 0.008 & 0.00194 & $0.064 \times 10^{-3}$ \\
\hline $\begin{array}{l}\text { MMC } \\
\text { (FA) }\end{array}$ & 3.741 & 3.735 & 0.006 & 0.00145 & $0.048 \times 10^{-3}$ \\
\hline
\end{tabular}

Table. 7: Wear Test Result of Forging Sample (Room Temp) Constant Load, RPM, Time and Temp

\begin{tabular}{llllll}
\hline Material & $\begin{array}{l}\text { Initial } \\
\text { Weight } \\
\text { (in } \\
\text { gm) }\end{array}$ & $\begin{array}{l}\text { Final } \\
\text { Weight } \\
\text { (in } \\
\text { gm) }\end{array}$ & $\begin{array}{l}\text { Loss } \\
\text { Of } \\
\text { Weight } \\
\text { (in } \\
\text { gm })\end{array}$ & $\begin{array}{l}\text { Wear } \\
\text { Rate= } \\
\text { Vol. } \\
\text { Loss/SD } \\
\left(\mathrm{mm}^{3} / \mathrm{m}\right)\end{array}$ & $\begin{array}{l}\text { Specific } \\
\text { Wear Rate } \\
\left(\mathrm{mm}^{3} / \mathrm{Nm}\right)\end{array}$ \\
\hline $\begin{array}{l}\text { Al6061 } \\
\text { alloy }\end{array}$ & 3.784 & 3.767 & 0.017 & 0.00418 & $\begin{array}{l}0.139 \\
\mathrm{x} 10-3\end{array}$ \\
\hline $\begin{array}{l}\text { MMC } \\
\text { (RHA) }\end{array}$ & 3.590 & 3.574 & 0.016 & 0.00391 & $\begin{array}{l}0.130 \\
\mathrm{x} 10-3\end{array}$ \\
\hline $\begin{array}{l}\text { MMC } \\
\text { (FA) }\end{array}$ & 3.732 & 3.719 & 0.011 & 0.00271 & $\begin{array}{l}0.090 \\
\mathrm{x} 10-3\end{array}$ \\
\hline
\end{tabular}


Table. 8: Wear Test Result of Forging Sample (At $150^{\circ} \mathrm{C}$ ) Constant Load, RPM, Time and Temp

\begin{tabular}{|c|c|c|c|c|c|}
\hline Material & $\begin{array}{l}\text { Initial } \\
\text { Weight } \\
\text { (in } \\
\text { gm) }\end{array}$ & $\begin{array}{l}\text { Final } \\
\text { Weight } \\
\text { (in } \\
\text { gm) }\end{array}$ & $\begin{array}{l}\text { Loss Of } \\
\text { Weight } \\
\text { (in gm) }\end{array}$ & $\begin{array}{l}\text { Wear } \\
\text { Rate= } \\
\text { Vol. } \\
\text { Loss/SD } \\
\left(\mathrm{mm}^{3} / \mathrm{m}\right)\end{array}$ & $\begin{array}{l}\text { Specific } \\
\text { Wear Rate } \\
\left(\mathrm{mm}^{3} / \mathrm{Nm}\right)\end{array}$ \\
\hline $\begin{array}{l}\text { Al6061 } \\
\text { Alloy }\end{array}$ & 3.416 & 3.408 & 0.008 & 0.00196 & $0.065 \times 10^{-3}$ \\
\hline $\begin{array}{l}\text { MMC } \\
\text { (RHA) }\end{array}$ & 3.683 & 3.678 & 0.005 & 0.00122 & $0.040 \times 10^{-3}$ \\
\hline $\begin{array}{l}\text { MMC } \\
\text { (FA) }\end{array}$ & 3.738 & 3.736 & 0.002 & 0.00049 & $0.016 \times 10^{-3}$ \\
\hline
\end{tabular}
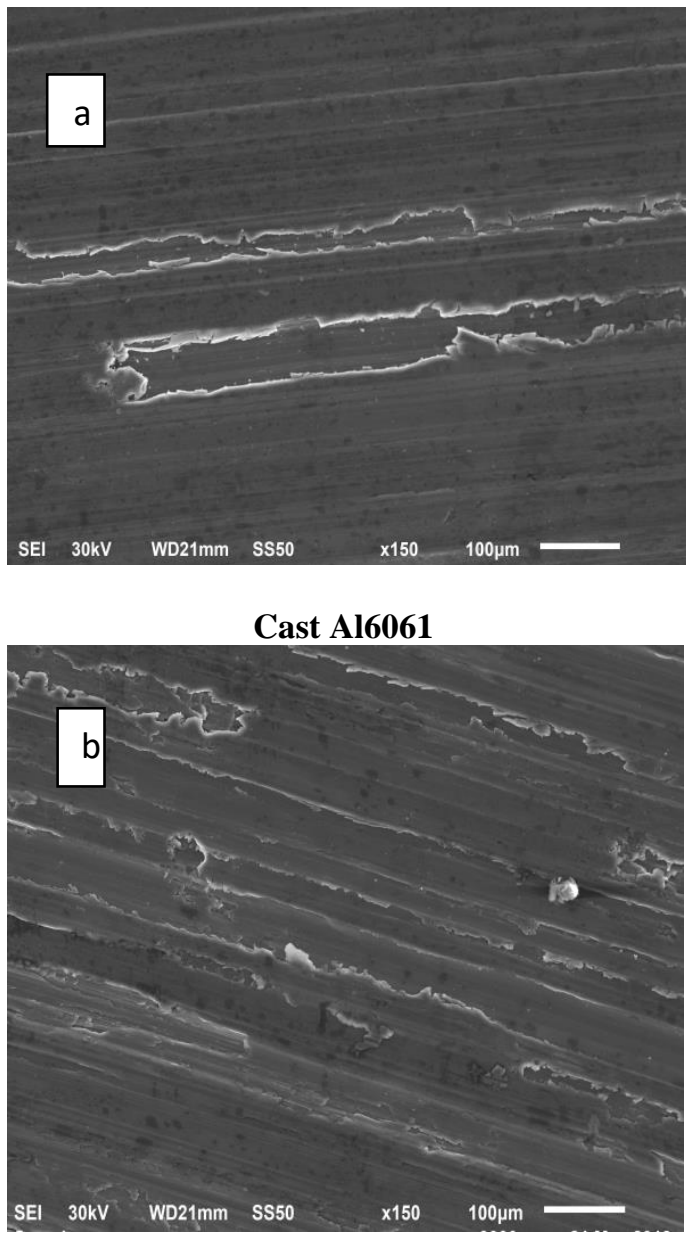

Cast Al6061/RHA

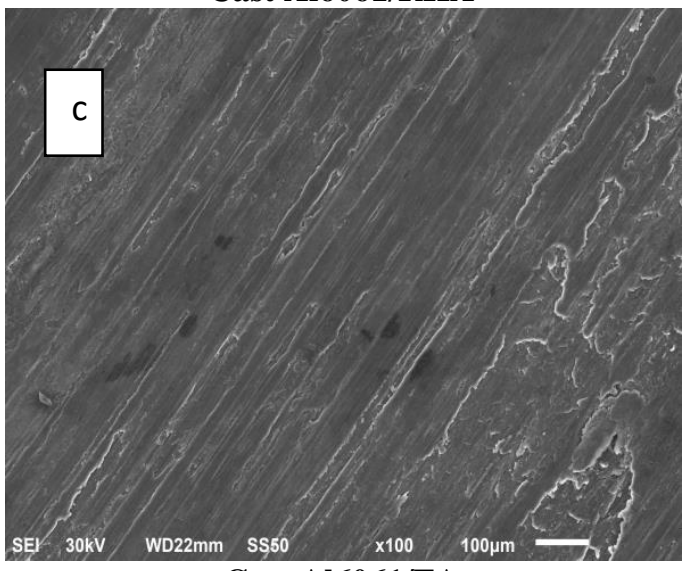

Cast Al6061/FA

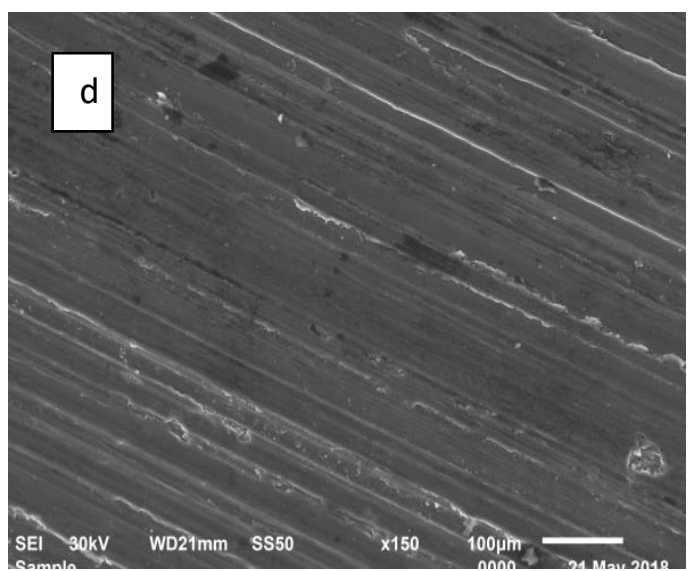

Forged Al6061

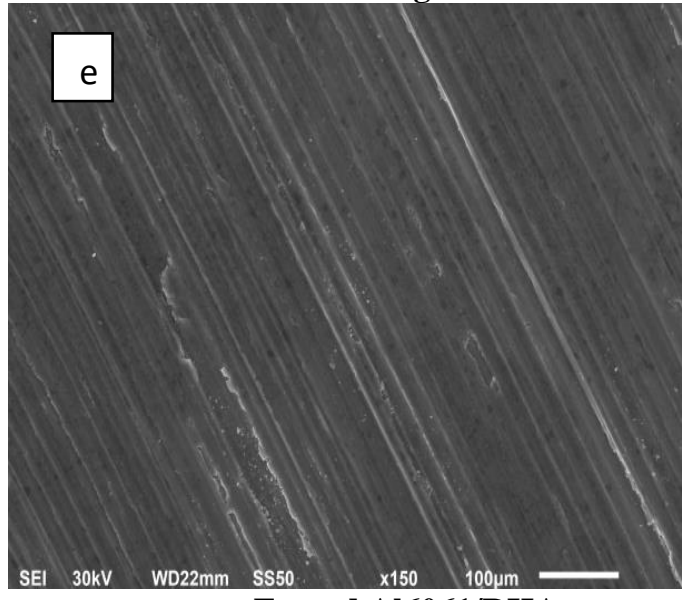

Forged Al6061/RHA

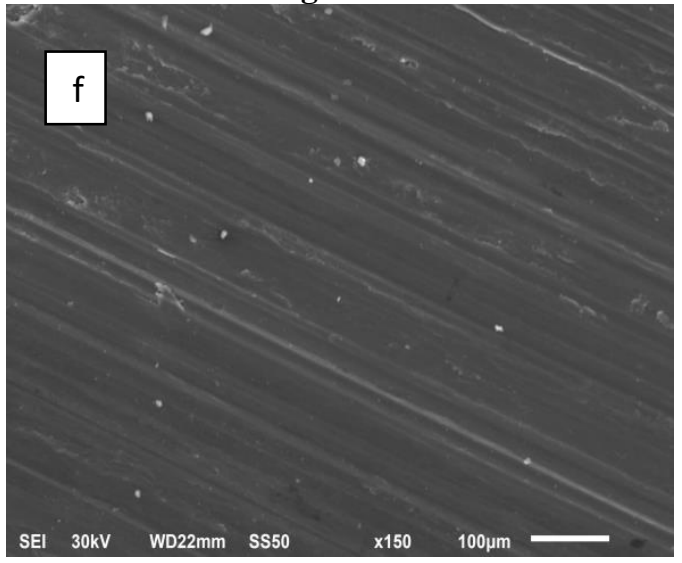

Forged Al6061/FA

SEM micrographs show the extent of grooving is less in both the matrix alloy and composites on forging Fig. 5 (a-f). Due to which the wear rate of the forged matrix alloy and its composite were lower in comparison to cast alloy, shown in Fig. 5(a).Granular plate like debris particles observed to be present in the grooves. Form the above observation it was found that Al6061/FA composites exhibits least wear rate.

\section{CONCLUSION}

Form the Present investigation it was concluded that

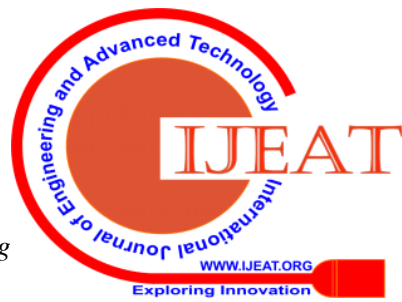


I. The stir casting techniques was successfully adopted for the preparation of as cast Al6061 alloy, Al6016/RHA and Al6061/FA composite. The composites and matrix alloy hot forged by $80 \%$ in different step. Hot forging gives better mechanical bonding between matrix and reinforcement compared to as cast composite.

II. Microstructure revel that forging did not promote damage on the composite and it also minimizes the porosity of the composite.

III. Forging improves the mechanical properties without hampering the ductility, this is due to super plastic deformation during forging.

IV. Wear rate of forged composites lower than that of cast one in all test condition. The forged Al6061/FA composite material had shown least wear rate at $150^{\circ} \mathrm{C}$ in comparison with its room temperature wear, this is because formation of work hardened layer.

\section{REFERENCES}

1. P. Cavaliere, E. Cerri, E. Evangelista, Isothermal forging modelling of $2618+20 \%$ Al2O3p metal matrix composite, Journal of Alloys and Compounds, vol. 378, (1-2), (2004), pp. 117-122

2. Hashim J., Looney L., Hashmi M.S.J., 2001. The enhancement of wettability of $\mathrm{SiC}$ particles in cast aluminium matrix composites, Journal of Material Processing Technology, Vol. 119, pp. 329-335.

3. Klimowicz T.F., 1994. The large scale commercialization of aluminium-matrix composites, Journal of the Minerals, Metals and Materials Society, Vol. 46, pp. 49-53

4. Sachin, Y; Wear behavior of aluminium alloy and its composites reinforced by $\mathrm{SiC}$ particles using statical analysis; Material and design, 2003,24,95-103.

5. C.S. Ramesh, R. Keshavamurthy, Influence of forging on mechanical properties of Ni-P coated Si3N4 reinforced Al6061 composites, Mat. Sci. Eng. A, 551 (2012) 59- 66

6. Stefanos Skolianos, Mechanical behavior of cast SiCp-reinforced Al4.5\% Cu-1.5\% mg alloy,Mat. Sci. Eng. A, 210 (1996) $76-82$.

7. S. B. Venkata Siva, K. L. Sahoo, R. I. Ganguly, R. R. Dash, Effect of Hot Working on Structure and Tribological Properties of Aluminium Reinforced with Aluminium Oxide, Journal of Materials Engineering and Performance, 21, (2012) 1226-1231.

8. Y.H. Seo, C.G. Kang, Effects of hot extrusion through a curved die on the mechanical properties of $\mathrm{SiCp} / \mathrm{Al}$ composites fabricated by meltstirring, Composites Science and Technology, 59, (1999) 64365410.1016/s0266-3538(98)00123-7

9. R. Keshavamurthy, S.Suhael Ahmed, A.Mudashi Laxman, N.H.Anil Kumar, M.N.Shashidhara, Y.Vimarshan Reddy, Tribological properties of Hot forged Al2024-TiB2in-situ composite, Advanced Materials Manufacturing \& Characterization Vol 4 Issue 2 (2014) pp87-92.

10. M.J. Tan, L.H. Koh, K.A. Khor, and F.Y.C. Boey, Discontinuous reinforcementsin extruded aluminium-lithium matrix composites, Journal of Material ProcessTechnology 1993;37:391-403.

11. J.E. Allison and G.S. Cole, Metal-Matrix Composites in the Automotive Industry: Opportunities and Challenges, JOM, 1993, 45, p 19-24

12. M. Roy, B. Venkataraman, V.V. Bhanuprasad, Y.R. Mahajan, and G. Sundararajan, The Effect of Particulate Reinforcement on the Sliding Wear Behavior of Aluminium Matrix Composites, Metall. Trans. A, 1992, 23, p 2833-2847.

\section{AUTHORS PROFILE}

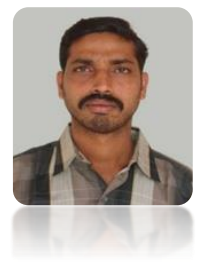

Gopal Krushna Mohanta persuing his $\mathrm{PhD}$ at CUTM, Parlakhemundi, Odisha, India. Also working as an assistant Professor at GIET University. His research area includes Metal Matrix Composite, Production, and Welding. He has published five technical articles in international journals.

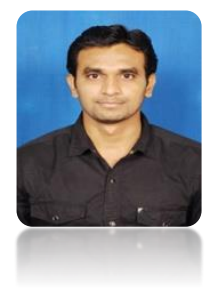

Sasank Shekhar Panda persuing his $\mathrm{PhD}$ at CUTM, Parlakhemundi, Odisha, India. Also working as an assistant Professor at GIET University. His research area includes Aluminim Metal Matrix Composite, Production, and machine design and simulation. He has published five technical articles in international journals.

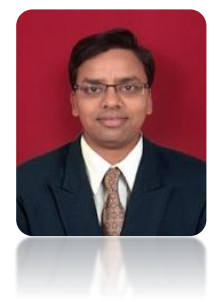

Ajit Kumar Senapati received his doctoral degree from KIIT University, Bhubaneswar, Odisha, India. His research area includes Metal Matrix Composite, Production, stir casting and Welding. He has Published five Peer-reviewed international journals. 